\title{
ISOTOPIC FRACTIONATION IN A SNOW-WATER SYSTEM
}

(Abstract)

by

M. Nakawo

(Institute of Snow and Ice Studies, NRCDP, Suyoshi-Machi, Nagaoka 940, Japan)

and

S. Chiba

(Department of Applied Physics, Faculty of Engineering, Hokkaido University, Sapporo 060, Japan)

Experiments were carried out to examine isotopic fractionation during the grain coarsening of snow particles soaked in water. The $\delta^{18} \mathrm{O}$ values of both snow and water changed with time, having a trend towards homogenization, that is the difference in the $\delta^{18} \mathrm{O}$ values for snow and water decreased. The results indicated that the final $\delta^{18} \mathrm{O}$ value of water was more negative than that of snow, corresponding to the fractionation factor between the solid and the melt. A simple model has explained the experimental data qualitatively, but modifications would have to be made before it could be used to give quantitative predictions for changes in $\delta^{18} \mathrm{O}$ values.

\section{USING STABLE ISOTOPES FOR DELINEATION OF DRAINAGE BASINS ON THE GREENLAND ICE-SHEET MARGIN FOR USE IN PLANNING HYDRO-ELECTRIC POWER SUPPLY, ILULISSAT/JAKOBSHAVN, WEST GREENLAND}

\author{
(Abstract) \\ by \\ Niels Reeh \\ (Alf red-Wegener-Institut für Polar- und Meeresforschung, Columbusstrasse, D-2850 Bremerhaven, \\ Federal Republic of Germany) \\ and \\ Henrik Højmark Thomsen
}

(Grønlands Geologiske Undersøgelse, Øster Voldgade 10, DK-1350 København K, Denmark)

Stable-isotope analysis of surface snow and firn samples from the accumulation zone of the Greenland ice sheet has shown that the ratio $\delta,{ }^{18} \mathrm{O} /{ }^{16} \mathrm{O}$, displays a systematic spatial variation over the ice-sheet surface, reflecting the variation in mean annual temperature. This results in a positive trend in $\delta$ from the high cold central regions of the accumulation zone towards the lower warmer areas near the equilibrium line. In the ablation zone along the margin of the ice sheet the ice, originally deposited as snow in the inland accumulation zone, re-appears at the surface. The nearer the position in which the snow was originally deposited is to the ice divide, the closer will be the position relative to the ice margin at which the corresponding ice will re-surface. The isotopic composition of the surface ice in the ablation area will therefore display a large spatial variation, reflecting a corresponding variation in the deposition area. Consequently, $\delta$ can be used as a natural tracer for the melt-water run-off from the ice-sheet margin. A model has been designed to simulate the variation in $\delta$ of this melt-water run-off, using as input the elevation distributions of drainage-basin area, melt rate, and $\delta$, and the elevation of the run-off line, which is the line on the ice-sheet surface below which run-off occurs, as a function of time through the melt season. The simulated variation in $\delta$ depends strongly on the elevation distribution of the drainage-basin area. Observed isotopic ratios in water samples from three pro-glacial lakes at Paakitsup Akuliarusersua, about $40 \mathrm{~km}$ north-east of Jakobshavn, West Greenland, are qualitatively in agreement with the simulated values. This agreement is improved by using the drainage cells determined from detailed mapping of the supraglacial drainage system, and from the surface $\delta$ distribution, indicating that the method has a general potential for delineating drainage basins on the ice-sheet margin. 